\title{
12. OXYGEN AND STRONTIUM ISOTOPE COMPOSITIONS OF HESS DEEP GABBROS (HOLES 894F AND 894G): HIGH-TEMPERATURE INTERACTION OF SEAWATER WITH THE OCEANIC CRUST LAYER $3^{1}$
}

\author{
Christophe Lécuyer ${ }^{2,3}$ and Gérard Gruau ${ }^{2}$
}

\begin{abstract}
The Hess Deep Rift Valley exposes a young $(\approx 1 \mathrm{Ma})$ section of lower oceanic crust generated at the East Pacific Rise (EPR). The drillers recovered $154 \mathrm{~m}$ of plutonic rocks from Hole 894G. The mineralogy and textures of these rocks suggest that they represent the roof of a magma chamber. These high-level gabbros, olivine-gabbros, and gabbronorites are slightly hydrated (average LOI $=0.75 \%, N=27$ ) and crosscut by a few olivine basaltic dikes. The dikes were altered under greenschist facies conditions, and the gabbros were amphibolitized. Most of the gabbros have $\mathrm{Sr}$-isotopic ratios that range from 0.70247 to 0.70309 , indicative of low water-rock ratios $(<1)$, with a circulating fluid having a ${ }^{87} \mathrm{Sr} /{ }^{86} \mathrm{Sr}$ ratio calculated at 0.7032 . The $\delta^{18} \mathrm{O}$ values of the gabbros range from 2.2 to 6.5 and are generally much lower (average $\delta^{18} \mathrm{O}=4.8, N=31$ ) than the mantle reference value $(5.7 \pm 0.2)$, whereas olivine basalts do not show any ${ }^{18} \mathrm{O}$ depletion. The $\delta^{18} \mathrm{O}$ values of clinopyroxenes are often anomalously low (5.1-5.3). Clinopyroxene-plagioclase fractionation values reach 1.5 and reveal strong isotopic disequilibrium attributed to high-temperature isotopic exchange with a discrete aqueous fluid. Clinopyroxenes with $\delta^{18} \mathrm{O} \approx 5$ contain minute $\mathrm{Mg}$-rich amphibole lamellae (1-5 mm) that represent a very early stage of high-temperature alteration before altering totally into amphibole. Except for a few samples with isotopic compositions that were reequilibrated at low temperatures $\left(<200^{\circ} \mathrm{C}\right)$, the gabbros contain low- $\delta^{18} \mathrm{O}$ plagioclase $\left(\delta^{18} \mathrm{O}=3-5\right)$ that recrystallized at high temperatures $\left(400^{\circ}-600^{\circ} \mathrm{C}\right)$ without exchanging major cations $\left(\mathrm{An}_{50-65}\right)$. The Hess Deep gabbros record mechanisms of isotopic exchanges governed by percolation of fluids along grain boundaries and self-diffusion of oxygen through plagioclase without involving macroscopic brittle deformation. These water-rock interactions produced a sequence of low- ${ }^{18} \mathrm{O}$ oceanic rocks early in the spreading history of the EPR that can be compared with the gabbro sequence of the Oman ophiolite.
\end{abstract}

\section{INTRODUCTION}

The opening of the Hess Deep Rift has tectonically exhumed young $(\approx 1 \mathrm{Ma})$ lower crustal and upper mantle rocks that were generated at the East Pacific Rise (EPR). During Leg 147 of the Ocean Drilling Program (ODP), we cored gabbroic sections (Holes 894F and $894 \mathrm{G}$ ) that provide an unique opportunity for studying the hydrothermal interactions between seawater and the lower levels of the oceanic crust generated at a fast-spreading ridge. Within the highlevel gabbros of Holes 894F and 894G, a well-developed vein and crack network records low-temperature channeled fluid flow $\left(<350^{\circ} \mathrm{C}\right)$ that was contemporaneous with the thermal contraction of the crust (Gillis, Mével, Allan, et al., 1993).

The role of solid state diffusion during fluid circulation is generally neglected in the total budget of the hydrothermal alteration of the oceanic crust even though it should provide information about the early on-axis high-temperature hydrothermal activity $\left(>350^{\circ} \mathrm{C}\right)$. The pervasive circulation of fluids at grain boundaries through plutonic rocks must be examined"at a location where hot hydrothermal fluids are expected to react with high-level gabbros. If temperatures in the hydrothermal system are high enough, hot fluids percolate along grain boundaries and react at the grain scale through dissolution-pre-

'Mével, C., Gillis, K.M., Allan, J.F., and Meyer, P.S. (Eds.), 1996. Proc, ODP, Sci. Results, 147: College Station, TX (Ocean Drilling Program).

${ }^{2}$ Laboratoire de Géochimie Isotopique, Géosciences Rennes, UPR 4661 CNRS, Université de Rennes 1, Campus de Beaulieu, F-35042 Rennes, France. Gruau: gruau@univ-rennes1.fr

'Current address: Laboratoire de Sciences de la Terre, URA 726 CNRS, Ecole Normale Supérieure, 46 Allée d'Italie, 69364 Lyon cedex 07, France.

clecuyer@geologie.ens-lyon.fr cipitation or diffusion mechanisms (e.g., self-diffusion of oxygen in plagioclase). Consequently, mineralogic alteration and isotopic exchange may develop far from major discontinuities (veins, cracks) and participate in the thermal cooling of the crust as well as in chemical and isotope exchange with seawater.

If subsolidus hydrothermal alteration of gabbros is pervasive and occurs at high temperatures, their initial oxygen isotopic compositions must be shifted toward lower $\delta^{18} \mathrm{O}$ values at the contrary of basalts and most dikes of oceanic layer 2 . An accurate knowledge of the oxygen isotope budget established during oceanic crust-seawater interactions is an important key to determine how the oxygen isotope composition of the world ocean evolves through time. On the basis of oxygen isotope measurements of dredged oceanic gabbros and mass balance calculations, Muehlenbachs and Clayton (1976) proposed that the $\delta^{18} \mathrm{O}$ value of the oceans is buffered at a value near zero by isotopic exchange between seawater and oceanic crust. Gregory and Taylor (1981) and Stakes and Taylor (1992), who have studied the Oman ophiolite, found that the ${ }^{18} \mathrm{O}$ enrichment of basalts and dikes balances the ${ }^{18} \mathrm{O}$ depletion of the gabbros in different profiles of the fossil oceanic crust. However, oxygen isotope studies of ophiolites like Xigaze (Agrinier et al., 1988) and Trinity (Lécuyer and Fourcade, 1991) revealed a global ${ }^{18} \mathrm{O}$ enrichment of the deep-level rocks. Holes $894 \mathrm{~F}$ and $894 \mathrm{G}$ in the Hess Deep Rift Valley provide the opportunity to validate the existence of low $\delta^{18} \mathrm{O}$ gabbros drilled in an intact part of oceanic layer 3. We sampled undeformed gabbros mainly metamorphosed under amphibolite facies conditions (called "static metamorphism") to study the thermal and chemical effects of their high-temperature alteration by seawater. Strontium and oxygen isotope measurements were performed on gabbros selected far from any kind of major discontinuity (shear zone, crack, vein). In situ oxygen isotope ratios were obtained on single plagioclase and pyroxene 
grains to examine how water-rock interactions extend down to the subgrain scale. Thus, the "background alteration" of Hess Deep gabbros will be characterized in terms of (1) metamorphic assemblages, (2) rates of hydration, (3) closure temperatures for oxygen isotopes, and (4) water-rock ratios.

\section{ANALYTICAL TECHNIQUES}

We determined mineral modes (volume percentages) visually or by point counting (see also Gillis, Mével, Allan, et al., 1993). Loss on ignition (LOI) was either determined on the JOIDES Resolution or at the University of Rennes (Table 1).

Oxygen was extracted from rock powders using the $\mathrm{BrF}_{5}$ method (Clayton and Mayeda, 1963) and analyzed as $\mathrm{CO}_{2}$ gas on a VG SIRA 10 mass spectrometer at the University of Rennes. Isotopic compositions are quoted in the standard $\delta$ notation relative to SMOW. Results from the NBS28 standard gave $\delta^{18} \mathrm{O}=+9.5 \% \circ \pm 0.2 \% \circ\left(2 \sigma_{\mathrm{m}}\right)$.

We obtained $\delta^{18} \mathrm{O}$ values for mineral separates using microcores extracted from thick sections of rock chips; consequently, these analyses gave the compositions of individual mineral grains, not averaged values as typically provided by conventional techniques of mineral separation. The amount of material extracted by this method is typically 1-3 mg of powder. Thick sections are used to check if contamination by neighboring minerals occurs during the drilling procedure. The identification of minerals was performed by Raman spectroscopy, either in the vicinity of microcores or on residual powders.

We determined the $\mathrm{Sr}$-isotope compositions (Table 1) following the method of Jahn et al. (1980). Sr blanks were lower than $1.10^{-9} \mathrm{~g}$. ${ }^{87} \mathrm{Sr} /{ }^{86} \mathrm{Sr}$ ratios were measured using a five-collector Finnigan MAT262 mass spectrometer. All ratios were normalized against ${ }^{86} \mathrm{Sr} /{ }^{88} \mathrm{Sr}$ $=0.1194$ for isotopic fractionation. Results from the NBS987 Sr standard on 15 separate runs yielded ${ }^{87} \mathrm{Sr} /{ }^{86} \mathrm{Sr}=0.71023 \pm 2\left(2 \sigma_{\text {pop }}\right)$, and all ${ }^{87} \mathrm{Sr} /{ }^{86} \mathrm{Sr}$ ratios presented in this paper were corrected by +0.00002 to be consistent with the NBS reference value of 0.71025 .

\section{PETROLOGY}

Hole $894 \mathrm{~F}$ and the upper part of Hole $894 \mathrm{G}$ are dominated by gabbros and olivine gabbros that are crosscut by basaltic dikes with chilled contacts against the wallrocks. Deeper in Hole 894G, gabbronorite represents the most abundant rock type and contains a few olivine gabbronorite layers.

The Hess Deep gabbros are characterized by a "static metamorphism" (rocks metamorphosed in the absence of deformation at the rock or grain scale) whose extent is highly variable with depth; the percentage by volume of secondary minerals ranges from $5 \%$ to $80 \%$. Mineral assemblages suggest that this metamorphism began under amphibolite facies conditions characterized by the following mineral association: $\mathrm{Mg}$-rich amphibole (tremolite) + Ca-rich plagioclase. Retrograde metamorphic reactions under greenschist facies conditions can be also found in some samples showing an association of Na-rich plagioclase (albite-oligoclase) + actinolite \pm chlorite \pm talc \pm epidote.

Brittle deformation, which accompanied the thermal contraction of the plutonic rocks, has developed a dense vein network observable all along the core. Both macroscopic ( $\geq 0.01 \mathrm{~mm}$ wide) and microscopic veins occur in the gabbros of Site 894 (Manning and MacLeod; Manning et al., this volume). Optical microscopy reveals that the early generation of veins are microscopic and filled with amphibole: they are considered to be related to the pervasive and static amphibolite facies mineral assemblages ("background alteration"). All macroscopic veins postdate the microscopic veins and are characterized by greenschist or zeolite facies assemblages. A first generation of these veins are filled with amphibole \pm chlorite \pm titanite. They are followed by anastomosing fractures filled with actinolite \pm chlorite \pm epidote \pm prehnite \pm smectite and typically associated with extensive wallrock alteration that extends at least $10 \mathrm{~cm}$ from the veins. The youngest macroscopic veins, commonly subvertical, are filled with a typical zeolite facies mineral association: chlorite \pm smectite \pm mixed-layer clays \pm zeolites \pm calcite, which can be found as coatings on core pieces or as late residual pore filling in earlier vein types.

Olivine is generally strongly altered in the range from 50 to 100 vol\%. When olivine relicts are still present, they are rimmed by a coronitic association of chlorite, iddingsite, talc, and tremolite. Replacement of pyroxenes by amphibole and minor chlorite is the main manifestation of alteration in Hess Deep gabbros but remains heterogeneous from one sample to another one $(10 \%-100 \%$ alteration by volume). Tiny secondary clinopyroxene patches, commonly associated with brown-green amphibole lamellae, occur as replacement of magmatic clinopyroxenes, whereas discrete patches of talc sometimes invade the orthopyroxene cores.

Plagioclase looks fresh in most of the gabbro samples, but turbid grains containing numerous and very tiny iron exsolutions are also present. Fluid inclusions are often abundant along the crystal rims. In highly altered zones, the formation of albitic plagioclase dominates. Inclusions or patches of clays and zeolites are common in plagioclase grains close to anastomosing macroscopic vein networks filled with low-temperature minerals.

The extent of alteration in basaltic dikes is also highly variable, with $10 \%$ to $85 \%$ replacement of primary mineralogy by volume. The metamorphic mineral assemblage lacks any evidence of amphibolite facies. The mineral associations that characterize the greenschist and zeolite facies observed in gabbros occur both in the background alteration of the dikes and in their associated macroscopic and microscopic veins.

For studying the mechanisms of background alteration affecting the Hess Deep gabbro succession of Holes $894 \mathrm{~F}$ and $894 \mathrm{G}$, samples were selected randomly along the core independent of the texture and primary mineralogy variations. However, except for Sample 147$894 \mathrm{G}-2 \mathrm{R}-3,20-26 \mathrm{~cm}$, which was collected close to a low-temperature macroscopic vein, sites close to any kind of macroscopic open fracture, vein network, and associated alteration halo were avoided.

\section{RESULTS Oxygen Isotopes}

We analyzed 35 whole rocks (Table 1 ) and 16 microcored minerals (Table 2) for oxygen isotope compositions. In Figure 1, wholerock $\delta^{18} \mathrm{O}$ values are plotted vs. depth (meters below seafloor [mbsf]) for Holes $894 \mathrm{~F}$ and $894 \mathrm{G}$. The $\delta^{18} \mathrm{O}$ values for gabbros vary widely and range from 2.2 to 6.5 , but $60 \%$ of the data range from 4.5 to 5.0 , revealing a significant ${ }^{18} \mathrm{O}$ depletion for this sequence of high-level gabbros relative to the mantle reference of $5.7 \pm 0.2$ (Pineau et al., 1976). Sample $147-894 \mathrm{G}-2 \mathrm{R}-3,20-26 \mathrm{~cm}$, the only gabbro sampled close to a macroscopic vein network, has the highest $\delta^{18} \mathrm{O}$ value of 6.5. $\delta^{18} \mathrm{O}$ variations with depth commonly reach $1 \%$ by meter. The distribution of $\delta^{18} \mathrm{O}$ values does not show any regular trend of isotopic enrichment or depletion with depth (Fig. 1). The lowest $\delta^{18} \mathrm{O}$ values are found within $100 \mathrm{~m}$ below the surface whereas $\delta^{18} \mathrm{O}$ values close to $5.3 \%$ characterize Hole $894 \mathrm{G}$ from 100 to $150 \mathrm{~m}$. Hess Deep gabbros show a combination of low $\delta^{18} \mathrm{O}$ values (down to 2.2) and low LOI $(<0.5 \%)$. However, the inverse is also seen: $\delta^{18} \mathrm{O}$ values lower than 5 associated with high LOI values up to $2.5 \%$ (Table 1).

Four olivine basalts (Table 1), which are interpreted as dikes crosscutting the gabbro sequence (Gillis, Mével, Allan, et al., 1993), have $\delta^{18} \mathrm{O}$ values slightly lower (5.3 and 5.5) or slightly higher (6.1) than the mantle reference value $(5.7 \% \circ \pm 0.2 \%$ o).

$\delta^{18} \mathrm{O}$ values of microcored minerals are only available for pyroxene, plagioclase, chlorite, and ilmenite (Table 2). Amphibole was not analyzed because of the common mixing of this mineral with minute 
Table 1. Oxygen and strontium isotope compositions of gabbros and basalts from Holes $894 \mathrm{~F}$ and $894 \mathrm{G}$.

\begin{tabular}{|c|c|c|c|c|c|c|c|c|}
\hline $\begin{array}{l}\text { Core, section, } \\
\text { interval }(\mathrm{cm})\end{array}$ & $\begin{array}{c}\text { Piece } \\
\text { no. }\end{array}$ & $\begin{array}{l}\text { Depth } \\
\text { (mbsf) }\end{array}$ & $\begin{array}{l}\text { Rock } \\
\text { type }\end{array}$ & $\begin{array}{l}\text { Alteration } \\
(\text { vol\%) }\end{array}$ & LOI & $\begin{array}{c}\delta^{18} \mathrm{O} \\
\% o(\mathrm{SMOW})\end{array}$ & $\begin{array}{c}\mathrm{Sr} \\
(\mathrm{ppm})\end{array}$ & ${ }^{87} \mathrm{Sr} /{ }^{86} \mathrm{Sr}$ \\
\hline \multicolumn{9}{|l|}{ 147-894F- } \\
\hline \multicolumn{9}{|l|}{$147-894 \mathrm{G}-$} \\
\hline $2 R-1,60-65$ & 9 & 29.20 & pl-ol basalt & 12 & 1.80 & 5.3 & 88 & 0.702642 \\
\hline $2 \mathrm{R}-1,85-92$ & 11 & 29.45 & pl-ol basalt & & 1.38 & 5.3 & & \\
\hline $2 \mathrm{R}-2,95-100$ & 15 & 31.05 & pl-ol basalt & 20 & 1.84 & 5.5 & 88 & \\
\hline $2 \mathrm{R}-3,20-26$ & 4 & 31.75 & ol-gb & 85 & 4.05 & 6.5 & 65 & 0.704297 \\
\hline $2 \mathrm{R}-3,109-115$ & 14 & 32.64 & ol-gb & 33 & & 5.2 & 79 & \\
\hline $4 \mathrm{R}-1,113-119$ & 16 & 46.13 & gb-norite & 26 & 0.40 & 5.1 & 92 & 0.702577 \\
\hline $5 \mathrm{R}-1,30-34$ & 5 & 50.30 & gb-norite & & 0.57 & 4.7 & 92 & 0.702588 \\
\hline $6 R-1,94-100$ & $8 \mathrm{~A}$ & 55.74 & gb-norite & & 0.95 & 4.9 & & \\
\hline $6 \mathrm{R}-2,79-87$ & 6 & 57.02 & gb-norite & 22 & 0.52 & 4.6 & 83 & 0.702629 \\
\hline $7 \mathrm{R}-1,56-66$ & 11 & 65.36 & ol-gb-norite & 23 & 0.70 & 4.7 & 89 & 0.702569 \\
\hline $7 R-1,76-84$ & 13 & 65.56 & gb-norite & 31 & 0.48 & 4.1 & 100 & \\
\hline $8 R-2,87-90$ & 8 & 70.87 & gb-norite & & 0.34 & 4.8 & & \\
\hline $9 \mathrm{R}-2,88-93$ & $5 B$ & 76.53 & gb-norite & & 0.35 & 4.8 & & \\
\hline $9 R-3,133-139$ & 11 & 78.24 & ol-gb-norite & 42 & 0.72 & 5.2 & 99 & 0.702688 \\
\hline $9 \mathrm{R}-4,100-144$ & $8-12$ & 79.33 & ol-gb-norite & 33 & 0.70 & 4.9 & 105 & \\
\hline $10 \mathrm{R}-1,105-111$ & 15 & 80.15 & $\mathrm{gb}$ & & 0.77 & 5.0 & & \\
\hline IIR-2, $100-107$ & 10D & 86.56 & gb-norite & 15 & 0.49 & 5.0 & 92 & 0.702513 \\
\hline II $-3,1-3$ & 1 & 87.01 & gb-norite & & 0.13 & 4.7 & & \\
\hline $11 R-3,17-28$ & $3 \mathrm{~A}$ & 87.17 & gb-norite & & & 4.9 & 79 & 0.702489 \\
\hline IIR-3, 31-38 & 4 & 87.31 & gb-norite & 30 & 0.45 & 5.2 & 90 & \\
\hline $12 \mathrm{R}-1,45-51$ & 6 & 94.25 & gb-norite & & 1.27 & 5.5 & & \\
\hline $12 \mathrm{R}-2,37-45$ & $4 \mathrm{E}$ & 95.63 & gb-norite & 22 & 1.27 & 4.7 & 111 & 0.702584 \\
\hline $12 \mathrm{R}-3,137-142$ & $8 \mathrm{~A}$ & 98.1 & gb-norite & & 0.75 & 5.3 & & \\
\hline $12 \mathrm{R}-5,122-125$ & $11 \mathrm{~B}$ & 100.95 & gb-norite & & 0.27 & 4.4 & & \\
\hline $13 R-2,6-13$ & IB & 104.83 & gb-norite & 30 & 0.65 & 2.2 & 111 & 0.702574 \\
\hline $13 R-2,90-98$ & 8 & 105.67 & gb-norite & 33 & 0.41 & 4.3 & 93 & \\
\hline $13 R-3,17-24$ & 1B & 106.40 & gb-norite & 32 & & 4.1 & 88 & 0.702511 \\
\hline $15 \mathrm{R}-1,32-35$ & 6 & 119.12 & gb-norite & 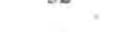 & 1.59 & 5.7 & & \\
\hline $17 \mathrm{R}-1,50-58$ & $10 \mathrm{~A}$ & 126.30 & gb-norite & 6 & 0.42 & 5.4 & 85 & 0.702474 \\
\hline $18 \mathrm{R}-1,82-85$ & $10 \mathrm{~A}$ & 131.72 & gb-norite & & 1.42 & 5.2 & & \\
\hline $19 \mathrm{R}-1,49-55$ & 9 & 140.99 & pl-ol basalt & 80 & 2.83 & 6.1 & 91 & 0.703090 \\
\hline $19 \mathrm{R}-1,84-96$ & 13 & 141.34 & gb-norite & 56 & 0.40 & 4.4 & 106 & 0.702966 \\
\hline $20 \mathrm{R}-1,87-91$ & 15 & 146.47 & gb-norite & & 2.58 & 4.8 & & \\
\hline $20 \mathrm{R}-3,66-71$ & 10 & 148.08 & gb-norite & & 0.75 & 5.6 & & \\
\hline
\end{tabular}

Notes: Estimated volume of alteration, loss on ignition, and $\mathrm{Sr}$ concentrations are also reported for discussion in the text. The error presented on the ${ }^{87} \mathrm{Sr} /{ }^{86} \mathrm{Sr}$ ratio is the statistical error obtained during the mass spectrometry run. The true error, including other error sources such as instrumental reproducibility, is estimated to be close to \pm 30 . Total uncertainty on the $\delta^{18} \mathrm{O}$ values with respect to the SMOW is estimated to be lower than $0.1 \%$ to $0.15 \%$. $\mathrm{LOI}=$ loss on ignition. gb $=$ gabbro, pl-ol basalt $=$ plagioclase-olivine basalt, gb-norite $=$ gabbronorite, $\mathrm{ol}-\mathrm{gb}=$ olivine gabbro, and ol-gb-norite $=$ olivine gabbronorite.

grains of iron oxides, talc, and pyroxene. Plagioclase has a wide range of $\delta^{18} \mathrm{O}$ values $(3.0 \% 0-6.4 \%)$, contrasting with the more homogenous compositions of pyroxenes $(5.1 \% 0-5.7 \%$ ). Pyroxenes from Hess Deep have slightly lower $\delta^{18} \mathrm{O}$ values than those typical of fresh magmatic pyroxene from a MORB mantle source (Muehlenbachs and Clayton, 1972; Pineau et al., 1976; Kyser, 1986). The exception is Sample $147-894 \mathrm{G}-15 \mathrm{R}-1,32-35 \mathrm{~cm}$, with a $\delta^{18} \mathrm{O}$ value of 5.7 (Table 2). One analysis of clinopyroxene in Sample 147-894G$20 \mathrm{R}-1,87-91 \mathrm{~cm}$, gave a surprisingly low $\delta^{18} \mathrm{O}$ value of 3.5 . The powder produced during the microcoring was examined by Raman spectroscopy, which revealed a mixture of clinopyroxene and amphibole. P. Agrinier (pers. comm., 1994) and G. Früh-Green (pers. comm., 1994) reported $\delta^{18} \mathrm{O}$ values of amphibole in gabbros as low as $2 \%$, and this could explain the low $\delta^{18} \mathrm{O}$ value for our pyroxene. Analyses of two chlorites gave $\delta^{18} \mathrm{O}$ values of 8.2 and 5.3 in gabbro samples characterized by whole-rock $\delta^{18} \mathrm{O}$ values of 5.7 and 5.5 , respectively. One analysis of fresh ilmenite $\left(\mathrm{FeTiO}_{3}=96.5 \%, \mathrm{MnTiO}_{3}\right.$ $=3 \%$, and $\mathrm{MgTiO}_{3}=0.5 \%$ ) yielded a $\delta^{18} \mathrm{O}$ value of 2.6 , typical of TiFe oxides that preserve a magmatic composition with limited subsolidus reequilibration in the presence of pyroxene and plagioclase (Taylor and Epstein, 1962a, 1962b; Anderson et al., 1971).

\section{Strontium Isotopes}

Sr-isotope compositions of Hess Deep rocks range from 0.70247 to 0.70430 but most of them are lower than 0.7027 . Sample 147$894 \mathrm{G}-2 \mathrm{R}-3,20-26 \mathrm{~cm}$, the only sample close to a macroscopic vein network, has the highest initial Sr ratio and $\delta^{18} \mathrm{O}$ value (Table 1). This sample, which will be discussed further in the next section, clearly records late and low-temperature hydrothermal alteration and is not considered as belonging to the background alteration. Sr-isotope compositions for fresh mid-ocean ridge basalts (MORB) are commonly between 0.7023 and 0.7029 , with an average value of 0.70265 (Hart et al., 1974; Barrett and Friedrichsen, 1982). Any increase in the ${ }^{87} \mathrm{Sr} /{ }^{86} \mathrm{Sr}$ ratio can be attributed to the addition of seawater $\mathrm{Sr}$ (Dasch et al., 1973). No Hess Deep samples are totally fresh with respect to their mineralogy. Thus, to estimate the initial magmatic $\mathrm{Sr}$ ratio, which is required to quantify isotopic exchange with seawater, we need to use another approach. There is a rough correlation of the initial $\mathrm{Sr}$-isotope compositions with the estimated volume percentage of alteration, suggesting that $\mathrm{Sr}$-isotope variations within Holes $894 \mathrm{~F}$ and $894 \mathrm{G}$ are mainly controlled by the extent of hydrothermal alteration (Fig. 2). By extrapolation to a percentage of alteration equal to zero, an initial "magmatic" Sr-isotope ratio of 0.7024 is inferred. This value fits well with the previous range given for fresh MORB. We do not observe any positive correlation between the $\mathrm{Sr}$-isotope ratios and Sr concentrations, which suggests that the main mechanism of ${ }^{87} \mathrm{Sr}$ increase in Hess Deep gabbros was isotope exchange rather than a global strontium addition caused by mineral neoformation.

\section{DISCUSSION}

The Hess Deep gabbros show large $\delta^{18} \mathrm{O}$ variations $(4 \%$ ) at the meter scale within $150 \mathrm{~m}$ of drilled rocks (Fig. 1). These whole-rock $\delta^{18} \mathrm{O}$ values may depend on four parameters, including (1) the modal abundance of a mineral very sensitive to isotope exchange, (2) integrated fluid fluxes, (3) temperature, and (4) the isotope composition 
Table 2. Oxygen isotope compositions of microcored minerals for gabbros from Hole 894G.

\begin{tabular}{|c|c|c|c|c|c|c|}
\hline \multirow[b]{2}{*}{$\begin{array}{l}\text { Core, section, } \\
\text { interval }(\mathrm{cm})\end{array}$} & \multirow[b]{2}{*}{$\begin{array}{c}\text { Piece } \\
\text { no. }\end{array}$} & \multirow[b]{2}{*}{$\begin{array}{l}\text { Depth } \\
\text { (mbsf) }\end{array}$} & \multicolumn{4}{|c|}{$\delta^{18} \mathrm{O} \%$ (SMOW) } \\
\hline & & & Plagioclase & Pyroxene & Chlorite & IImenite \\
\hline \multicolumn{7}{|l|}{$147-894 \mathrm{G}-$} \\
\hline $6 \mathrm{R}-1,94-100$ & $8 \mathrm{~A}$ & 55.74 & 4.0 & 5.7 & & \\
\hline $8 R-2,87-90$ & 8 & 70.87 & 4.5 & 5.3 & & \\
\hline 9R-2, 88-93 & $5 B$ & 76.53 & 3.9 & 5.2 & & \\
\hline $1 \mid \mathrm{R}-3,1-3$ & 1 & 87.01 & 4.8 & 5.2 & & 2.6 \\
\hline $12 \mathrm{R}-1,45-51$ & 6 & 94.25 & 6.4 & 5.1 & 5.3 & \\
\hline $15 \mathrm{R}-1,32-35$ & 6 & 119.12 & 5.7 & & 8.2 & \\
\hline 20R-1, 87-91 & 15 & 146.47 & 3.0 & 3.5 & & \\
\hline
\end{tabular}

Notes: Total uncertainty on the $\delta^{18} \mathrm{O}$ values with respect to the SMOW is estimated to be lower than $0.1 \%$ to $0.15 \%$.

of the hydrothermal fluid (Brikowski and Norton, 1989). When we plot the whole-rock $\delta^{18} \mathrm{O}$ values against the estimated volume percentages of plagioclase, we do not see any significant correlation that could reveal a "modal effect" on the oxygen isotope compositions of the gabbros (Fig. 3). Such a correlation would not be expected if fluid fluxes are larger than reaction rates (Gregory et al., 1989).

\section{Strontium Isotopes}

The Sr-isotope compositions of the gabbros can be used to estimate water-rock ratios and the composition of the hydrothermal fluid. The water-rock ratios can be calculated using a simple mass balance equation (Albarède et al., 1981). This calculation requires that the Sr-isotope composition of a totally altered rock should be equal to the fluid in equilibrium. Holes $894 \mathrm{~F}$ and $894 \mathrm{G}$ do not provide a $100 \%$ altered rock; however, by extrapolating the linear relation of Figure 2, we can deduce a Sr-isotope composition of 0.7032 as a rough estimate of the hydrothermal fluid that reacted with the Hess Deep gabbros. For the hypothetical $100 \%$-altered rock, the mass balance equation provides a water-rock ratio of 1.4. Consequently, most of the Hess Deep gabbros reacted with a "mature" hydrothermal fluid developed in a rock-dominated system under water-rock ratios less than 1. It means that this fluid, whose composition is far from the initial Sr composition of seawater $(\approx 0.7091$; Burke et al., 1982), had already exchanged $\mathrm{Sr}$ isotopes before altering the high-level gabbros. McCulloch et al. (1980, 1981) found a similar relationship in the Samail ophiolite. The same phenomenon was also inferred from the calculated $\mathrm{Sr}$-isotope composition of the end-member fluid ${ }^{87} \mathrm{Sr} /{ }^{86} \mathrm{Sr}=$ 0.7038) that circulated through the sheeted dike complex of the East Pacific Rise sampled at Hole 504B (Kawahata et al., 1987). Sr-isotope compositions of Hole 504B veins crosscutting sheeted dikes indicate also that these hydrothermal solutions lie between 0.7031 and 0.7039 (Kawahata et al., 1987), well bracketing the calculated Hess Deep solution. These estimates also are in very good agreement with those measured in the hot fluids discharged at the East Pacific Rise at $21^{\circ} \mathrm{N}\left({ }^{87} \mathrm{Sr}{ }^{86} \mathrm{Sr}=0.7030\right.$; Albarède et al., 1981) and $13^{\circ} \mathrm{N}\left({ }^{87} \mathrm{Sr} /{ }^{86} \mathrm{Sr}\right.$ $=0.7041 ;$ Michard et al., 1984).

\section{Oxygen Isotopes}

The study of Holes $894 \mathrm{~F}$ and $894 \mathrm{G}$ gabbros provides the first evidence of the net ${ }^{18} \mathrm{O}$ depletion (Fig. 1) of an intact part of layer 3 formed at a modern fast-spreading ridge. The EPR basalts and dikes sampled at Hole 504B are ${ }^{18} \mathrm{O}$ enriched (Alt et al., 1986). Because no complete section of modern oceanic crust has been sampled, it is not yet possible to perform the types of mass balance calculations that have been done on the Samail ophiolite (Gregory and Taylor, 1981; Stakes and Taylor, 1992).
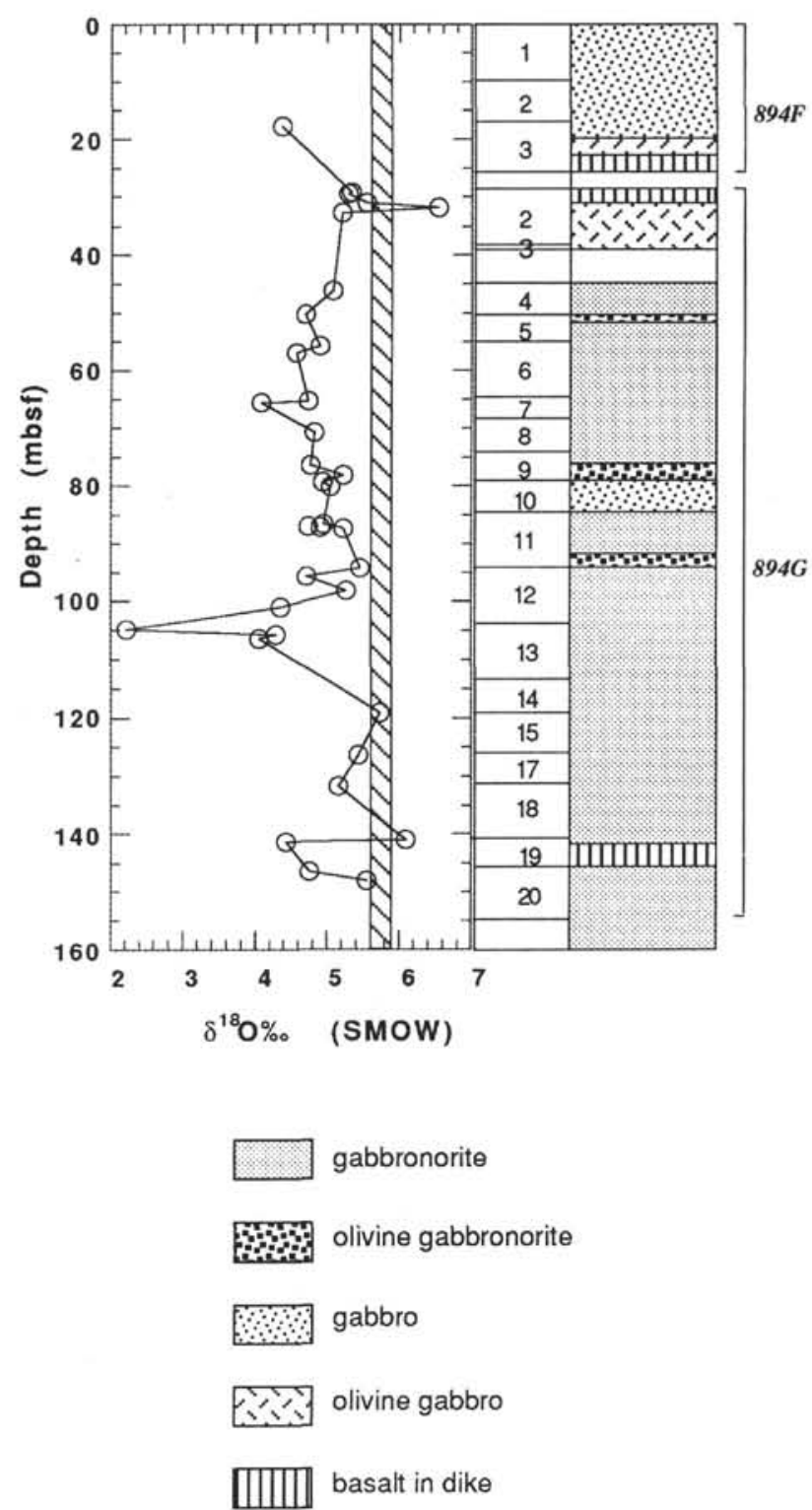

Figure 1. Distribution of whole-rock $\delta^{18} \mathrm{O}$ values with depth (meters below seafloor). The shaded area covers the oxygen isotope compositions of fresh magmatic rocks derived from an oceanic mantle source. Numbers in column refer to core sections.

Gabbros in the Hess Deep area were recovered for the first time in 1988 during a Nautile submersible dive program (Francheteau et al., 1990). P. Agrinier (pers. comm., 1994) investigated the stable isotope compositions of a large variety of rocks and found that most gabbros have $\delta^{18} \mathrm{O} \approx 5.6$, which is very close to their initial magmatic values. Calcic plagioclase has magmatic oxygen isotope compositions and does not show evidence of isotope exchange with a fluid phase. When isotope exchange occurs, this is mainly under greenschist facies conditions (P. Agrinier, pers. comm., 1994) and ${ }^{18} \mathrm{O}$ modified gabbros are those in which plagioclase is unstable (partly replaced by albite and/or prehnite).

The conditions of water-rock interactions recorded in the gabbros from Holes $894 \mathrm{~F}$ and $894 \mathrm{G}$ are drastically different from those dredged by the Nautile and reveal the complexity and heterogeneity 


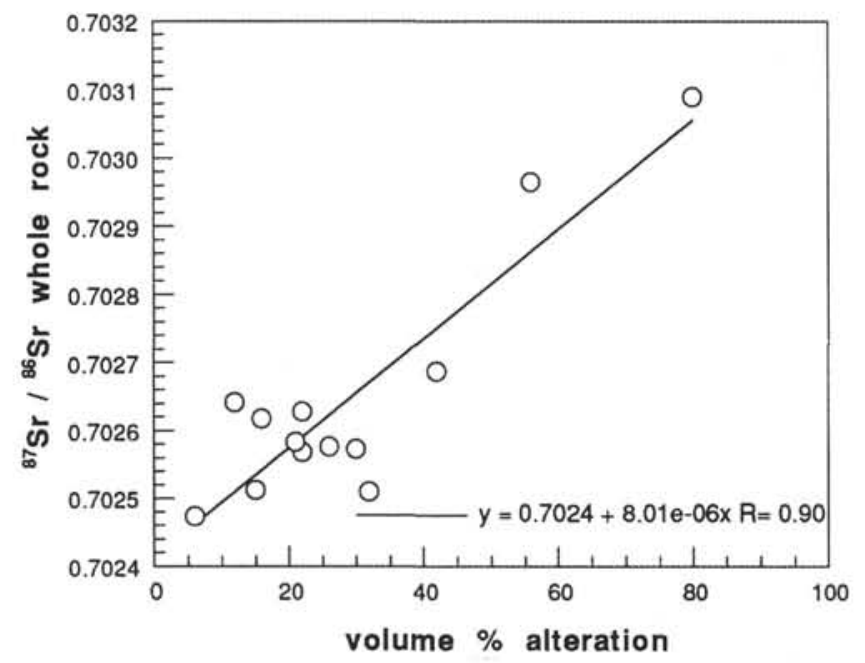

Figure 2. Variations of ${ }^{87} \mathrm{Sr} /{ }^{86} \mathrm{Sr}$ vs. the volume percentage of alteration. Sample $147-894 \mathrm{G}-2 \mathrm{R}-3,20-26 \mathrm{~cm}$, a gabbro very close to a macroscopic vein network, is excluded from this treatment. Only the background alteration is examined here.

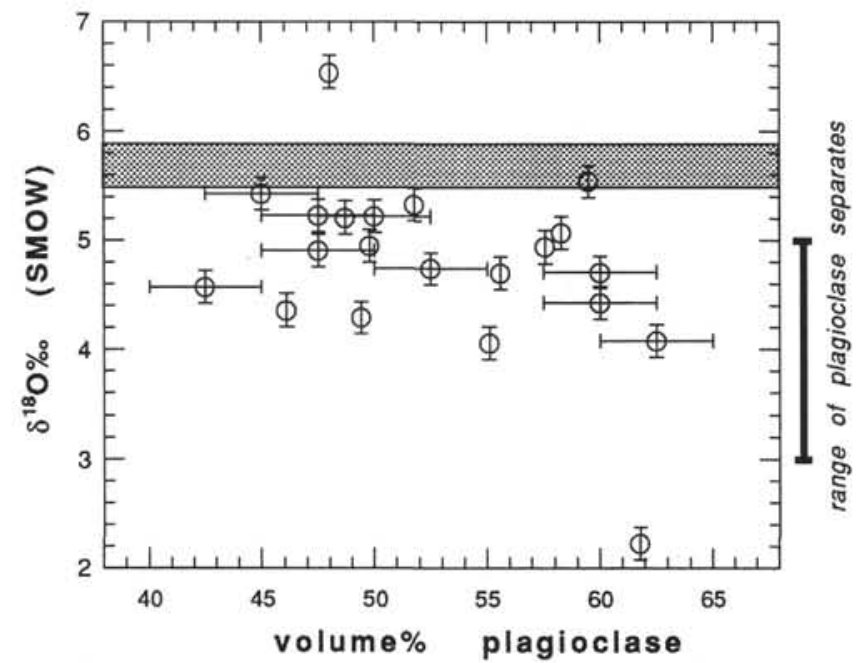

Figure 3. Variations of whole-rock $\delta^{18} \mathrm{O}$ values vs. the modal abundance of plagioclase.

of the alteration processes affecting the oceanic crust. The ${ }^{18} \mathrm{O}$ depletion that affects our collection of Hess Deep gabbros occurs in slightly hydrated rocks where the plagioclase remains calcic under amphibolite facies conditions $\left(\mathrm{An}_{50-65}\right.$ for plagioclases in Samples 147894G-6R-1, 94-100 cm; 11R-3, 1-3 cm, and 15R-1, 32-35 cm). Figure 4 gives the variation of $\delta^{18} \mathrm{O}$ values for some rock-forming minerals and shows that plagioclase $\left(3<\delta^{18} \mathrm{O}<5\right)$ is principally responsible for the global decrease of whole-rock $\delta^{18} \mathrm{O}$ values. In pyroxene, $\delta^{18} \mathrm{O}$ values range from 5.1 to 5.7 . The apparent oxygen isotope fractionation between pyroxene and plagioclase can reach up to 1.5 , a disequilibrium pattern already mentioned by Gregory and Taylor (1981) in the Oman ophiolite gabbros and by Ito and Clayton (1983) in samples from the Mid-Cayman slow-spreading center.

Assuming $\delta^{18} \mathrm{O}$ values of hydrothermal fluids that range from 0 to 2, as measured in hydrothermal vents (Craig et al., 1980; Craig, 1981) or as predicted by thermodynamic models (Bowers and Taylor, 1985), and water-rock ratios lower than 1, closure temperatures of hydrothermal alteration for plagioclases are calculated in the range from $400^{\circ} \mathrm{C}$ to $600^{\circ} \mathrm{C}$ using the mass-balance equation for open sys-
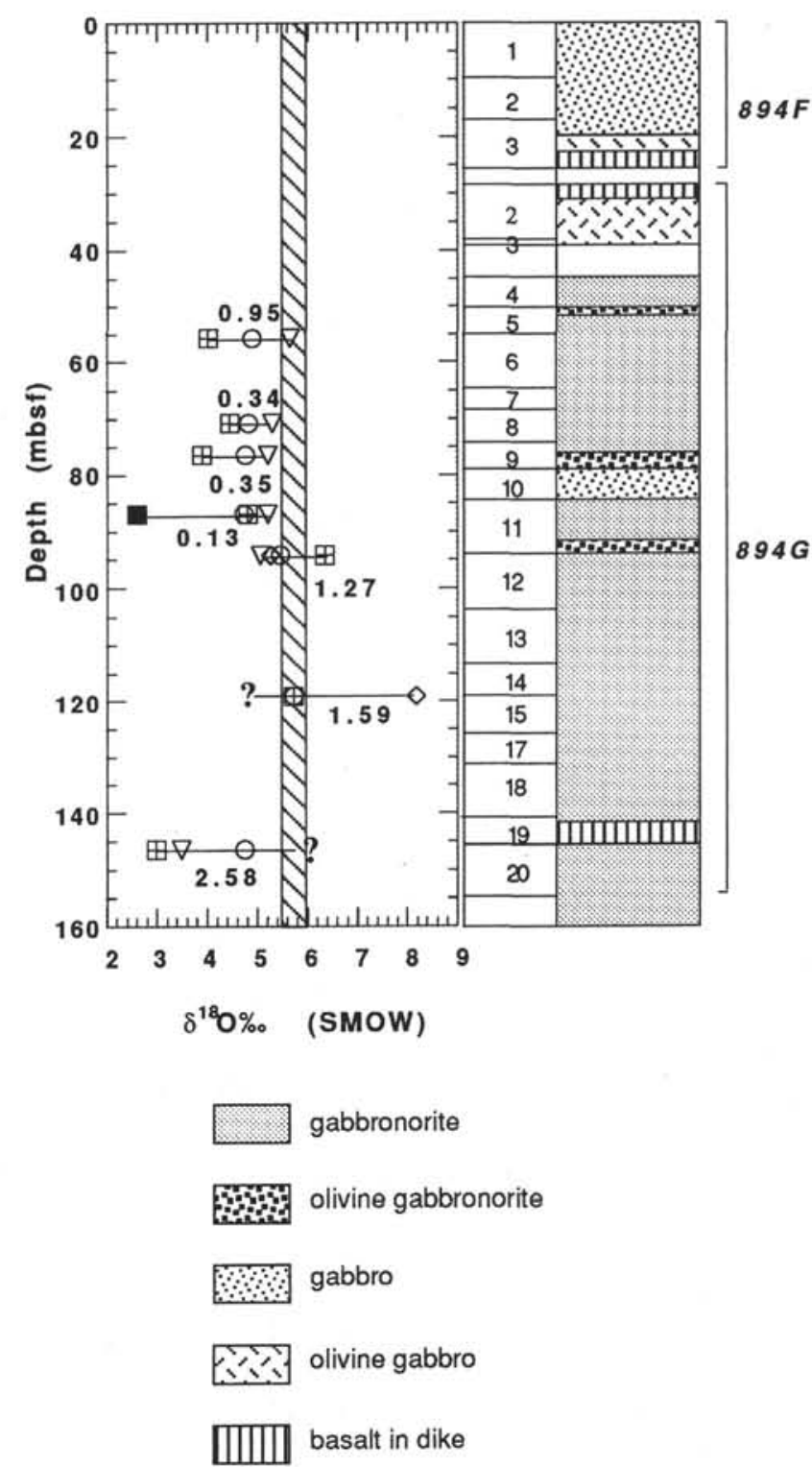

Figure 4. Distribution of mineral $\delta^{18} \mathrm{O}$ values with depth (meters below seafloor). The hatchured area shows the range of $\delta^{18} \mathrm{O}$ values of fresh magmatic rocks derived from an oceanic mantle source. Numbers in bold represent the loss on ignition. Other numbers refer to core sections.

tems proposed by Taylor (1977). These "isotopic temperatures" are in agreement with the pervasive presence of amphibolite assemblages throughout Hole $894 \mathrm{G}$.

Most magmatic pyroxenes are characterized by $\delta^{18} \mathrm{O}$ values in the range from 5.1 to 5.3 , which are lower than the expected value of 5.7 \pm 0.2 for mantle-derived pyroxenes (Taylor and Epstein, 1962a, 1962b; Anderson et al., 1971). Ito and Clayton (1983) analyzed clinopyroxenes from Mid-Cayman Rise gabbros that also have low $\delta^{18} \mathrm{O}$ values (from $4.8 \%$ to $5.0 \%$ ). Ito and Clayton (1983) attributed these isotope compositions to subsolidus exchange between clinopyroxenes, plagioclase, and $\mathrm{Fe}$ - $\mathrm{Ti}$ oxides during the slow cooling of the plutonic rocks. As a consequence of the subsolidus isotope reequilibration, plagioclase becomes ${ }^{18} \mathrm{O}$ enriched (slightly higher than 6), whereas pyroxene $(4.8-5.0)$ and $\mathrm{Fe}-\mathrm{Ti}$ oxide (down to 0.5 ) become ${ }^{18} \mathrm{O}$ depleted. A few mineral separates from Hess Deep gabbros do not support this hypothesis (Table 2). The existence of clinopyroxene 
(Sample 147-894G-6R-1, 94-100 cm) and ilmenite (Sample 147 $894 \mathrm{G}-11 \mathrm{R}-3,1-3 \mathrm{~cm}$ ) with $\delta^{18} \mathrm{O}$ values of 5.7 and 2.6 , respectively, suggests that these rocks that did not undergo significant subsolidus exchange.

The oxygen isotope composition of pyroxenes can be modified by exchange with a fluid phase at high temperature and with large amounts of fluids, as proposed by Gregory and Criss (1986) who studied pyroxene-plagioclase disequilibrium in gabbros from the Oman ophiolite. In the case of the Hess Deep gabbros, the Raman spectroscopic analysis reveals the existence of $\mathrm{OH}^{-}$groups trapped in the magmatic pyroxenes: these correspond to the presence of tiny (1$5 \mathrm{~mm}$ ) Mg-rich amphibole lamellae only detectable by a scanning electron microscopy (SEM) study (Lécuyer et al., 1993). These results reveal that plagioclase (the mineral most sensitive to oxygen isotope exchanges) governs the lowering of whole-rock $\delta^{18} \mathrm{O}$ values and that most pyroxenes were involved in oxygen isotope exchange with an aqueous phase. Despite the low water-rock ratios determined by the $\mathrm{Sr}$ isotopes, the fluid circulation is pervasive without involving macroscopic deformation such as faulting, cracking, or shearing. This is one of the most striking results inferred from the Hess Deep gabbros. Indeed, Ito and Clayton (1983) emphasized the strong relationship between the deformation (fracturing and shearing) and alteration of Mid-Cayman gabbros. In this area, similar oxygen isotope compositions were measured on amphibolitized gabbros.

In the case of Hess Deep, we propose that at temperatures of $400^{\circ}-600^{\circ} \mathrm{C}$, compatible with an early hydrothermal activity close to the ridge system, the fluid circulation is likely dominated by fluid percolation along grain boundaries and the isotopic exchange by oxygen self-diffusion through plagioclase. Indeed, the preservation of magmatic compositions and zonations of plagioclases (rims $\mathrm{An}_{50}$ and cores $\mathrm{An}_{65}$ ), and the absence of crystal deformation demonstrate that no major cation exchange with a fluid occurred, the low $\delta^{18} \mathrm{O}$ values can be simply accounted for by solid state diffusion of oxygen under hydrothermal conditions (Giletti et al., 1978). On the other hand, selfdiffusion of oxygen is too slow in pyroxenes (Farver, 1989), their oxygen isotope ratios were only slightly modified by the growth of tiny amphibole lamellae. In these conditions of high-temperature fluidrock interactions, significant oxygen isotopic exchanges (Fig. 5) can thus occur without involving a dramatic hydration of the rocks. These results reveal that channeled fluid flow in the oceanic layer 3 (Manning and MacLeod, this volume) is accompanied by pervasive fluid flow down to the grain scale during the high temperature hydrothermal stage that is responsible for both mineralogic and isotopic alteration of gabbros.

The four olivine basalts analyzed for their oxygen isotope compositions (Table 1; Fig. 1 ) do not show any evidence of ${ }^{18} \mathrm{O}$ depletion, a result that must be linked to the lack of amphibolite facies mineral assemblages. However, their oxygen isotope compositions remain close to those of a few strongly hydrated gabbros at the bottom of the Hole (Table 1; Fig. 1). Higher $\delta^{18} \mathrm{O}$ values relative to gabbros could be explained by lower closure isotopic temperatures as the consequence of the small grain size $(0.5 \mathrm{~mm})$ of these rocks. Higher hydration rates could be also caused by a fluid flow channeled along the dike margins, a process suggested by Nehlig and Juteau (1988) to promote fluid circulation in the sheeted dikes of the Oman ophiolite.

In terms of the oxygen isotope record, the alteration of Hess Deep gabbros is dominated by a high-temperature stage. Nevertheless, a low-temperature circulation overprints the early stage of hydrothermal alteration in the areas very close to the vein networks (for a more detailed study, see Früh-Green et al., this volume). This is the case for Sample $147-894 \mathrm{G}-2 \mathrm{R}-3,20-26 \mathrm{~cm}$, which has a whole-rock $\delta^{18} \mathrm{O}$ value of 6.5. Traces of the low-temperature event can also be found, surprisingly, in gabbros that show mantle-like oxygen ratios such as Sample 147-894G-15R-1, 32-35 cm $\left(\delta^{18} \mathrm{O}=5.7\right)$, and Sample 147$894 \mathrm{G}-12 \mathrm{R}-1,45-51 \mathrm{~cm}\left(\delta^{18} \mathrm{O}=5.5\right)$. Chlorite is generally present in gabbros that experienced some retrograde reactions into the green-

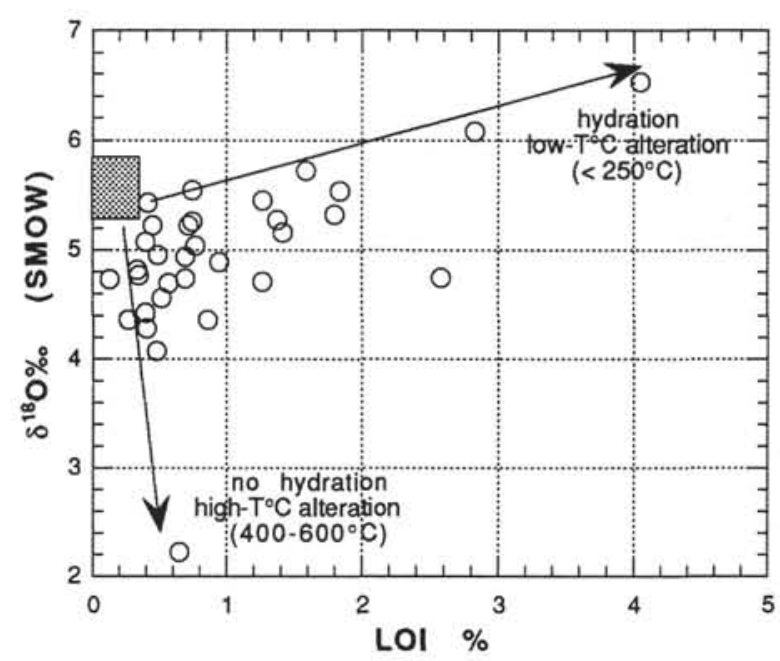

Figure 5. Variations of whole-rock $\delta^{18} \mathrm{O}$ values vs. loss on ignition. The hatchured area represents the field of fresh mantle-derived rocks.

schist or zeolite facies. Oxygen isotope composition of chlorite can be used as a thermometer if we take the fractionation equation serpentine/chlorite-water of Wenner and Taylor (1973) as a good approximation. In Sample 147-894G-15R-1,32-35 cm, chlorite occurs as isolated patches and has a high $\delta^{18} \mathrm{O}$ value (8.2), which suggests precipitation from seawater at a temperature that does not exceed $100^{\circ} \mathrm{C}$. This chlorite probably was contemporaneous with the vein network filled by the zeolite facies assemblage: chlorite, prehnite, and zeolite. Chlorites $\left(\delta^{18} \mathrm{O}=5.3\right)$ crystallized also at higher temperatures $\left(\approx 300^{\circ} \mathrm{C}\right)$ in the stability field of greenschist facies assemblages that occur in Sample 147-894G-12R-1, 45-51 cm (Table 2; Fig. 4). Früh-Green et al. (this volume) calculated approximate temperatures of $400^{\circ}-450^{\circ} \mathrm{C}$ for chlorites in serpentinized peridotites from Holes $895 \mathrm{C}$ and $894 \mathrm{E}$, which are characterized by lower $\delta^{18} \mathrm{O}$ values (from 1.5 to 3 ) than those analyzed in gabbros from Holes $894 \mathrm{~F}$ and $894 \mathrm{G}$. The large range of oxygen isotope compositions measured in chlorites from Hess Deep rocks reveals that this mineral is stable over a large span of temperatures during the hydrothermal alteration of the oceanic crust.

These results suggest that in some restricted areas the low-temperature fluids can overprint the high-temperature event that characterizes the background alteration (Fig. 5). This isotopic overprint is linked to the high densities of anastomosing macroscopic vein networks $\left(0.3 \mathrm{~cm}^{-1}\right)$ that occur in Cores $147-894 \mathrm{G}-2 \mathrm{R}, 4 \mathrm{R}, 6 \mathrm{R}, 12 \mathrm{R}$, 15R, and 20R (Gillis, Mével, Allan, et al., 1993; Manning et al., this volume). Apparently, the low-temperature fluids percolated through the wallrock and precipitated the greenschist facies or zeolite facies minerals responsible for the strong oxygen isotope disequilibrium between minerals observed in these gabbros.

\section{CONCLUSION}

Pervasive background alteration of the gabbros occurred without deformation under amphibolite facies conditions $\left(400^{\circ}-600^{\circ} \mathrm{C}\right)$ and was responsible for ${ }^{18} \mathrm{O}$ depletion of these rocks $\left(\delta^{18} \mathrm{O}=4.8, N=31\right)$. Plagioclase controls most of the oxygen isotope exchanges with the aqueous fluid phase. As a consequence, many low $\delta^{18} \mathrm{O}$ gabbros are only weakly hydrated (LOI $\leq 0.7 \%)$.

Water-rock ratios lower than 1 were calculated using $\mathrm{Sr}$ concentrations and isotope ratios. However these probably underestimate the real water-rock ratios because, as suggested by the oxygen isotope study, the $\delta^{18} \mathrm{O}$ value of plagioclase grains was lowered by self- 
diffusion of oxygen under hydrothermal conditions without modification of the major element chemistry $\left(\mathrm{An}_{50-65}\right)$.

A low-temperature fluid circulated in gabbroic levels where the vein density reaches $0.3 \mathrm{~cm}^{-1}$. This circulation led to whole-rock $\delta^{18} \mathrm{O}$ values close to normal mantle values $(5.5-5.7)$ or slightly higher values (6.5), and stronger hydration (LOI $=1 \%-2 \%)$,

Holes $894 \mathrm{~F}$ and $894 \mathrm{G}$ define, for the first time, a remarkable section of low $\delta^{18} \mathrm{O}$ gabbros hydrothermally altered beneath a fastspreading ridge. We do not yet know whether the ${ }^{18} \mathrm{O}$ depletion of Hole $894 \mathrm{G}$ gabbros is representative of the entire lower oceanic crust. In the absence of ${ }^{18} \mathrm{O}$-depleted gabbro zones, the oceans should evolve to lower $\delta^{18} \mathrm{O}$ values.

The existence of these low $\delta^{18} \mathrm{O}$ gabbros clearly validates the models of oceanic hydrothermal circulation elaborated on the basis of the Oman ophiolite. Gregory and Taylor (1981) presented an oxygen isotope profile in which gabbros clearly show a ${ }^{18} \mathrm{O}$ depletion similar to our Hess Deep samples.

These observations confirm that seawater-derived fluids react with the deep layers of the oceanic crust generated at fast-spreading ridges.

\section{ACKNOWLEDGMENTS}

The authors thank B. Reynard for the Raman spectroscopy analysis of pyroxenes and the interpretation of data. We are also indebted to F. Martineau and J. Macé for their assistance during analytical work conducted at the University of Rennes. C. Lécuyer is grateful to P. Grandjean for the compilation of references. N.T. Arndt is thanked for editing the manuscript. R.T. Gregory and R.J. Nevle are acknowledged for their constructive reviews that contributed to improve this manuscript.

\section{REFERENCES}

Agrinier, P., Javoy, M., and Girardeau, J., 1988. Hydrothermal activity in a peculiar oceanic ridge: oxygen and hydrogen isotope evidence in the $\mathrm{Xi}$ gaze ophiolite (Tibet, China). Chem. Geol., 71:313-335.

Albarède, F., Michard, A., Minster, J.F., and Michard, G., 1981. ${ }^{87} \mathrm{Sr} /{ }^{86} \mathrm{Sr} \mathrm{ra}-$ tios in hydrothermal water and deposits from the East Pacific Rise at $21^{\circ}$ N. Earth Planet. Sci. Lett., 55:229-236.

Alt, J.C., Muehlenbachs, K., and Honnorez, J., 1986. An oxygen isotopic profile through the upper kilometer of the oceanic crust, DSDP Hole 504B. Earth Planet. Sci. Lett., 80:217-229.

Anderson, A.T., Clayton, R.N., and Mayeda, T.K., 1971. Oxygen isotope thermometry of mafic igneous rocks. J. Geol., 79:715-729.

Barrett, T.J., and Friedrichsen, H., 1982. Strontium and oxygen isotopic composition of some basalts from Hole 504B, Costa Rica Rift, DSDP Legs 69 and 70. Earth Planet. Sci. Lett., 60:27-38.

Bowers, T.S., and Taylor, H.P., Jr., 1985. An integrated chemical and stableisotope model of the origin of midocean ridge hot spring systems. J. Geophys. Res., 90:12583-12606.

Brikowski, T., and Norton, D., 1989. Influence of magma chamber geometry on hydrothermal activity at mid-ocean ridges. Earth Planet. Sci. Lett. 93:241-255.

Burke, W.H., Denison, R.E., Hetherington, E.A., Koepnick, R.B., Nelson, H.F., and Otto, J.B., 1982. Variation of seawater ${ }^{87} \mathrm{Sr} /{ }^{86} \mathrm{Sr}$ throughout Phanerozoic time. Geology, 10:516-519.

Clayton, R.N., and Mayeda, T.K., 1963. The use of bromine pentafluoride in the extraction of oxygen from oxides and silicates for isotopic analysis. Geochim. Cosmochim. Acta, 27:43-52.

Craig, H., 1981. Hydrothermal plumes and tracer circulation along the East Pacific Rise: $20^{\circ} \mathrm{N}$ to $20^{\circ} \mathrm{S}$. Eos, $62: 893$. (Abstract)

Craig, H., Welhan, J.A., Kim, K., Poreda, R., and Lupton, J.E., 1980. Geochemical studies of the $21^{\circ} \mathrm{N}$ EPR hydrothermal fluids. Eos, 61:992 (Abstract)

Dasch, E.J., Hedge, C.E., and Dymond, J., 1973. Effect of sea water interaction on strontium isotope composition of deep-sea basalts. Earth Planet. Sci. Lett., 19:177-183.
Farver, J.R., 1989. Oxygen self-diffusion in diopside with application to cooling rate determinations. Earth Planet. Sci. Lett., 92:386-396.

Francheteau, J., Armijo, R., Cheminée, J.L., Hekinian, R., Lonsdale, P.F., and Blum, N., 1990. 1 Ma East Pacific Rise oceanic crust and uppermost mantle exposed by rifting in Hess Deep (equatorial Pacific Ocean). Earth Planet. Sci. Lett., 101:281-295.

Giletti, B.J., Semet, M.P., and Yund, R.A., 1978. Studies in diffusion, III. Oxygen in feldspars: an ion microprobe determination. Geochim. Cosmochim. Acta, 42:45-57.

Gillis, K., Mével, C., Allan, J., et al., 1993. Proc. ODP, Init. Repts., 147 College Station, TX (Ocean Drilling Program).

Gregory, R.T., and Criss, R.E., 1986. Isotopic exchange in open and closed systems. In Valley, J.W., Taylor, Jr., H.P., and O'Neil, J.R. (Eds.), Stable Isotopes in High Temperature Geological Processes. Mineral. Soc. Am., Reviews in Mineralogy, 16:91-126.

Gregory, R.T., Criss, R.E., and Taylor, H.P., Jr., 1989. Oxygen isotope exchange kinetics of mineral pairs in closed and open systems: applications to problems of hydrothermal alteration of igneous rocks and Precambrian iron formations. Chem. Geol., 75:1-42.

Gregory, R.T., and Taylor, H.P., Jr., 1981. An oxygen isotope profile in a section of Cretaceous oceanic crust, Samail ophiolite, Oman: evidence for $\delta^{18} \mathrm{O}$-buffering of the oceans by deep $(>5 \mathrm{~km})$ seawater-hydrothermal circulation at mid-ocean ridges. J. Geophys. Res., 86:2737-2755.

Hart, S.R., Erlank, A.J., and Kable, E.J.D., 1974. Sea floor basalt alteration: some chemical and $\mathrm{Sr}$ isotopic effects. Contrib. Mineral. Petrol., 44:219-230.

Ito, E., and Clayton, R.N., 1983. Submarine metamorphism of gabbros from the Mid-Cayman Rise: an oxygen isotopic study. Geochim. Cosmochim. Acta, 47:535-546.

Jahn, B.M., Bernard-Griffiths, J., Charlot, R., Cornichet, J., and Vidal, F., 1980. Nd and $\mathrm{Sr}$ isotopic compositions and REE abundances of Cretaceous MORB (Holes 417D and 418A, Legs 51, 52 and 53). Earth Planet. Sci. Lett., 48:171-184.

Kawahata, H., Kusakabe, M., and Kikuchi, Y., 1987. Strontium, oxygen and hydrogen isotope geochemistry of hydrothermally altered and weathered rocks in DSDP Hole 504B, Costa Rica Rift. Earth Planet. Sci. Lett., $85: 343-355$.

Kyser, T.K., 1986. Stable isotope variations in the mantle. In Valley, J.W., Taylor, H.P., Jr., and O'Neil, J.R. (Eds.), Stable Isotopes in High Temperature Geological Processes. Mineral. Soc. Am., Reviews in Mineralogy, 16:141-164.

Lécuyer, C., and Fourcade, S., 1991. Oxygen isotope evidence for multistage hydrothermal alteration at a fossil slow-spreading center: the Silurian Trinity Ophiolite (California, U.S.A.). Chem. Geol. (Isot. Geosci. Sect.), 87:231-246.

Lécuyer, C., Gruau, G., Reynard, B., Mével, C., and the Leg 147 Scientific Party, 1993. High-temperature diffusion of seawater through gabbroic rocks at Hess Deep Rift Valley, Leg 147. Eos, 74:653. (Abstract)

McCulloch, M.T., Gregory, R.T., Wasserburg, G.J., and Taylor, H.P., 1981. $\mathrm{Sm}-\mathrm{Nd}, \mathrm{Rb}-\mathrm{Sr}$, and ${ }^{18} \mathrm{O} /{ }^{16} \mathrm{O}$ isotopic systematics in an oceanic crustal section: evidence from the Samail ophiolite. J. Geophys. Res., 86:2721-2735.

McCulloch, M.T., Gregory, R.T., Wasserburg, G.J., and Taylor, H.P., Jr., 1980. A neodynium, strontium, and oxygen isotopic study of the Cretaceous Samail ophiolite and implications for the petrogenesis and seawater-hydrothermal alteration of oceanic crust. Earth Planet. Sci. Lett., 46:201-211.

Michard, G., Albarède, F., Michard, A., Minster, J.-F., Charlou, J.-L., and Tan, N., 1984. Chemistry of solutions from $13^{\circ} \mathrm{N}$ East Pacific Rise hydrothermal site. Earth Planet. Sci. Lett., 67:297-308.

Muehlenbachs, K., and Clayton, R.N., 1972. Oxygen isotope studies of fresh and weathered submarine basalts. Can. J. Earth Sci., 9:172-184.

Muehlenbachs, K., and Clayton, R.N., 1976. Oxygen isotope composition of the oceanic crust and its bearing on seawater. J. Geophys. Res., 81:43654369

Nehlig, P., and Juteau, T., 1988. Deep crustal seawater penetration and circulation at ocean ridges: evidence from the Oman Ophiolite. Mar. Geol., 84:209-228.

Pineau, F., Javoy, M., Hawkins, J.W., and Craig, H., 1976. Oxygen isotope variations in marginal basins and ocean ridge basalts. Earth Planet. Sci. Lett., 28:299-307.

Stakes, D.S., and Taylor, H.P., 1992. The northern Samail ophiolite: an oxygen isotope, microprobe, and field study. J. Geophys. Res., 97:70437080 
Taylor, H.P., and Epstein, S., 1962a. Relationship between $\mathrm{O}^{18} / \mathrm{O}^{16}$ ratios in coexisting minerals of igneous and metamorphic rocks, Part 1. Principles and experimental results. Geol. Soc. Am. Bull., 73:461-480.

,$- 1962 \mathrm{~b}$. Relationship between $\mathrm{O}^{18} / \mathrm{O}^{16}$ ratios in coexisting minerals of igneous and metamorphic rocks, Part 2. Applications to petrologic problems. Geol. Soc. Am. Bull., 73:675-694.

Taylor, H.P., Jr., 1977. Water/rock interactions and the origin of $\mathrm{H}_{2} \mathrm{O}$ in granitic batholiths. J. Geol. Soc. London, 133:509-558.
Wenner, D.B., and Taylor, H.P., 1973. Oxygen and hydrogen isotope studies of the serpentinization of ultramafic rocks in oceanic environments and continental ophiolitic complexes. Am. J. Sci., 273:202-239.

Date of initial receipt: 26 July 1994

Date of acceptance: 12 January 1995

Ms 147SR-014 